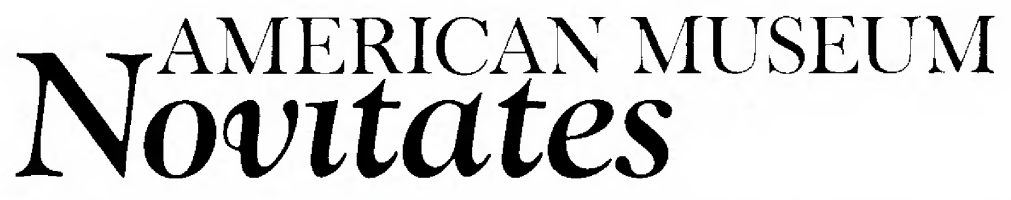

PUBLISHED BY THE AMERICAN MUSEUM
CENTRAL NATURAL HISTORY
Number 3311, 5 pp., 2 figures, 1 table

\title{
A New Permian Myalinid Genus, Elversella, of West Texas
}

\author{
CHRISTOPHER A. MCROBERTS ${ }^{1}$ AND NORMAN D. NEWELL ${ }^{2}$
}

\begin{abstract}
A distinctive myalinid bivalve Elversella rugosa new genus and species from the Middle Permian of West Texas is described. Elversella rugosa is characterized as being inequivalved, with a larger left valve covered rhythmically by coarse rugae and a smooth right valve that is somewhat smaller and less convex.
\end{abstract}

\section{INTRODUCTION}

The Myalinidae are a diverse group of marine and nonmarine bivalves represented in a variety of habitats from at least the Carboniferous to the Middle Triassic. Marine myalinids are noteworthy because of the many populations in the phylogeny of the Myalinidae (Newell, 1942) that display distinctive shell shapes and ornamentation. Despite significant morphological diversity, late Paleozoic myalinid genera are conservative in their development of hinge structures, which facilitates interpretation of their taxonomic relationships and evolutionary history.
The new species differs from other myalinids in the extraordinary, but not unique, ornamentation in the form of widely spaced, uniform rugae on the left valve. The right valve is smaller than the left one, a condition that has been termed discordancy (Newell and Merchant, 1939). This may indicate that the missing marginal portions of the right valve were composed of conchiolin that is only rarely fossilized. Like limids and some other pleurothetic bivalves, the right valve is unornamented and less convex than the left. In both valves the umbonal angle retains a low value throughout growth, resulting in accelerated posterior growth in the adult shell

\footnotetext{
${ }^{1}$ Research Associate, Division of Paleontology (Invertebrates), American Museum of Natural History; Assistant Professor, Department of Geology, State University of New York at Cortland, P.O. Box 2000, Cortland, New York 13045.

${ }^{2}$ Curator Emeritus, Division of Paleontology (Invertebrates), American Museum of Natural History.
} 


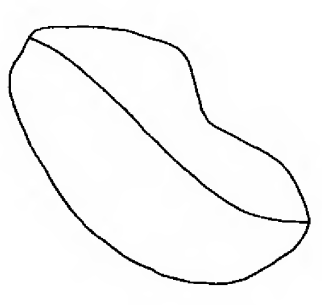

a

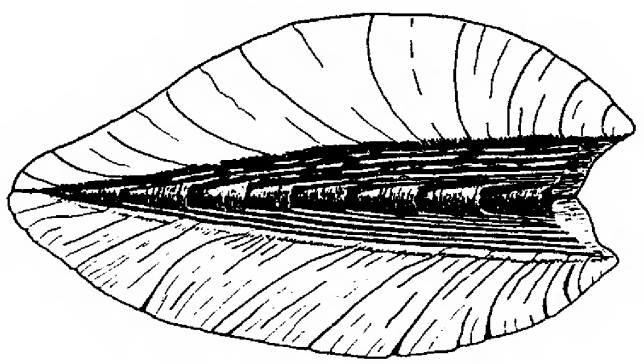

C
Fig. 1. a, b: Shape differences between two myalinids: Elversella (a) and Orthomyalina (b), demonstrating contrasting growth forms along the axis of the umbonal ridge. In Elversella, growth in the mature shell curves backward (retrocrescent), in Orthomyalina it is dominantly downward (infracrescent); c: Liebea, illustrating duplivincular ligament characteristic of all myalinids, as with Elversella (b and c after Newell, 1942: figs. 2 and 5 respectively).

(fig. 1a), a growth strategy referred to as retrocrescence. Furthermore, the umbonal angle decreases during ontogeny, enhancing the retrocrescent aspect characteristic of this new species. As in all myalinids, the ligament is duplivincular (fig. 1c). The significance of this new form is that it further exemplifies the remarkable taxonomic diversity of Permian Myalinidae (e.g., Newell, 1942; McRoberts and Newell, 1997).

Collection: The material before us includes fragments of many silicified valves from the U.S. National Museum of Natural History. They were collected by G.A. Cooper and his colleagues, in the Glass Mountains of West Texas, as byproducts of their search for brachiopods (Cooper and Grant, 1972). Unfortunately, the best specimens are incomplete.

\author{
SYSTEMATIC PALEONTOLOGY \\ ORDER PTERIOIDA NEWELL, 1965 \\ FAMILY MYALINIDAE FRECH, 1891
}

Genus Elversella McRoberts and Newell,
new genus

ETYMOLOGY: Named in honor of Walter B. Elvers.

TyPE SPECIES: Elversella rugosa McRoberts and Newell, new species.

DiAGNOSIS: Myalinidae with shell retrocrescent (sickle shaped) with discordant valves; left valve larger and more convex than right valve, with ten to fifteen coarse, commarginal rugae; right valve smaller, without ornamentation; shell edentulous, possessing simple opisthodetic duplivincular ligament, ligament grooves slightly curved, intersecting hinge margin at an angle of less than $45^{\circ}$.

RANGe AND Distribution: Lower and Middle Permian (Guadalupian) of West Texas (Glenister et al., 1992).

Elversella rugosa McRoberts and Newell, new species

Figure 2

Myalina squamosa?, Girty, 1908: 429, pl. 29, fig.

15, not Myalina squamosa Sowerby, which is a Devonian form.

ETYMology: Specific name refers to rugose ornamentation on the left valve.

Diagnosis: As for the genus.

DESCRIPTION: The valves are moderately small (maximum dimension generally less than $5 \mathrm{~cm}$ ). In profile, the beaks are conspicuous and extended forward above a broad and shallow anterior sinus. The umbonal ridge, which is poorly defined in later growth stages, curves down and backward at the margins, forming an angle of less than $45^{\circ}$ with the hinge at the rounded posteroventral extremity. The specimens bear five or six duplivincular ligament grooves that are slightly curved and intersect the hinge margin at an angle slightly less than $30^{\circ}$ (figs. 2.1, 2.5). The left valve bears as many as 15 coarse commarginal rugae, whereas the right valve is less convex and nearly smooth. Between the coarse rugae of the left valve are numerous fine commarginal growth lines. The right valve margin below the hinge lies well with- 


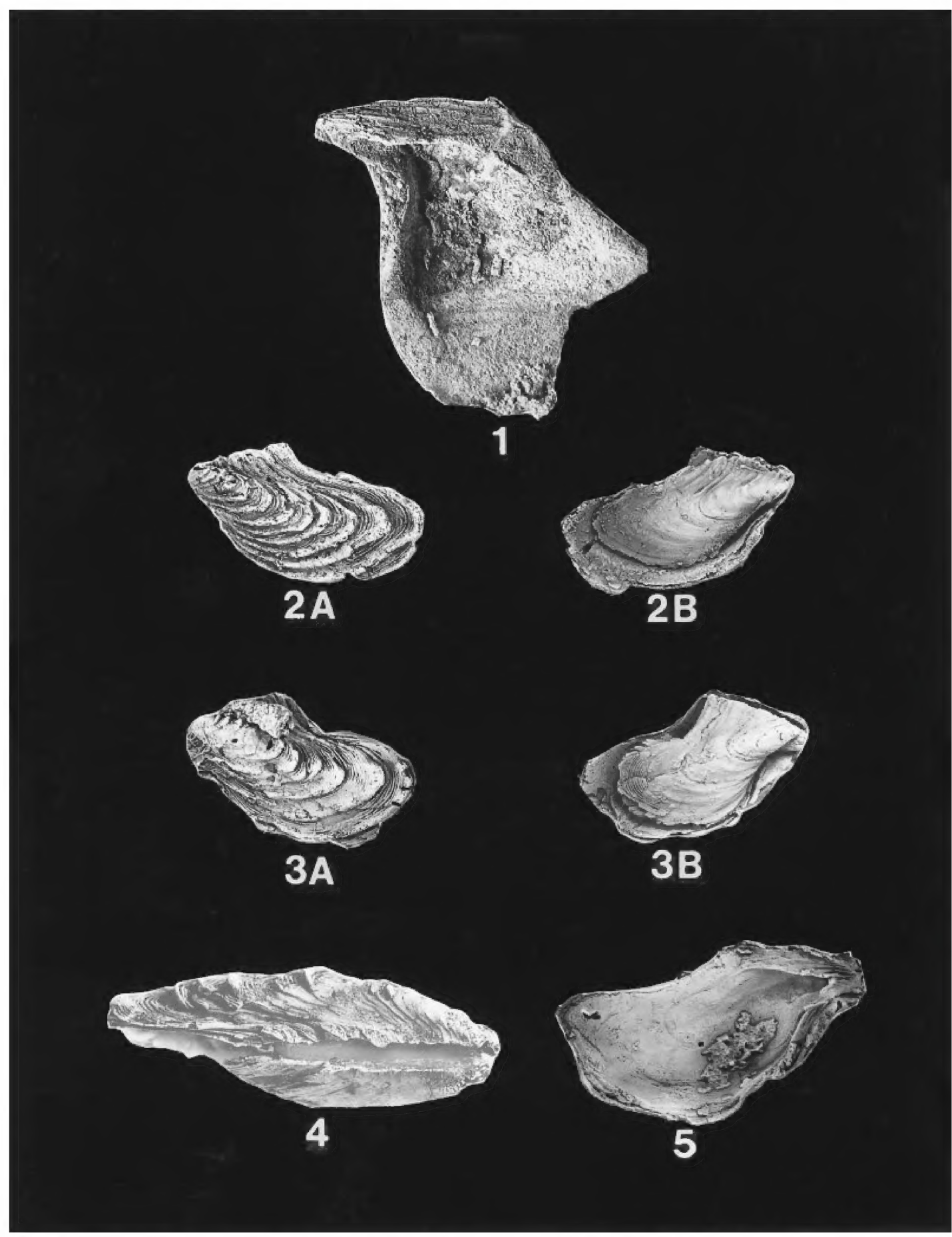

Fig. 2. Elversella rugosa, new species. All specimens somewhat enlarged; for true size see table 1. Specimens are from the Leonardian of West Texas, USNM locality 702d. 1. Interior of right valve showing myalinid hinge, USNM 431322; 2. Articulated specimen showing inequilateral valves characteristic of Elversella, 2A. left valve, 2B. right valve, overlapped by larger left valve, USNM 431323; 3. left and right views of articulated specimen, similar to 2, USNM 431324; 4. holotype, dorsal view of articulated specimen showing less convex right (lower) valve and myalinid hinge, USNM 431325; 5. left valve interior showing myalinid hinge, USNM 431326. 
TABLE 1

\section{Elversella rugosa McRoberts and Newell,} new species

Measurements in centimeters.

\begin{tabular}{cccclc}
\hline \hline Fig. & USNM No. & DM & LV & RV & R \\
\hline 2.1 & 431322 & 1.6 & - & $4.1^{*}$ & - \\
2.2 & 431323 & 1.4 & 3.3 & 2.6 & 12 \\
2.3 & 431324 & 1.4 & 3.2 & 2.6 & 12 \\
2.4 & 431325 & 2.2 & 4.4 & $3.5 *$ & 14 \\
& (holotype) & & & & \\
2.5 & 431326 & 1.6 & 4.0 & - & 15 \\
\hline
\end{tabular}

* = estimated from broken shell, DM = length of dorsal margin, $\mathrm{LV}=$ maximum dimension of left valve, $\mathrm{RV}=$ maximum dimension of right valve, $\mathrm{R}=$ number of prominent rugae on left valve.

in the edge of left valve; each valve bears a small posterodorsal auricle above a rounded sinus and byssal gape (figs. 2.1, 2.3A). The specimens contain a poorly preserved, but simple and continuous pallial line roughly parallel to the posteroventral margin (fig. 2.5). Further details of the musculature and shell microstructure are unknown due to poor preservation.

Material and Measurements: Our specimens are few and incomplete around the margins due to predepositional wear and breakage. The inequality in valve size suggests that some dissolution of the outer shell layer of the right valve, which may have been composed of conchiolin, occurred prior to silicification. The measurements (table 1) of the five specimens shown in figure 2 indicate variability and approximate size for the species.

DisCUSSION: This myalinid species is unlike any known to us. Elversella rugosa appears similar in outline and ornamentation to one of the several specimens Girty (1908: pl. 29, fig. 15) attributed to Myalina squamosa Sowerby from the Permian of the Glass Mts. and may therefore be conspecific. However, other Permian specimens attributed by Girty to M. squamosa (e.g, Girty, 1908: pl. 16, fig. 22) bear distinctively different ornamentation and lack an anterior auricle; therefore, they clearly represent a different species.

Elversella rugosa superficially resembles the equivalved Septimyalina burmai Newell, (1942: pl. 12, fig. 4) from the Florena Shale, (Wolfcampian); however, the new species lacks the umbonal septum of that form. $E$. rugosa is similar to several Aviculomyalina species known from Lower and Middle Triassic localities in Europe and North America (e.g., Assmann, 1937; McLearn, 1941). Unlike Elversella rugosa, however, Aviculomyalina is equivalved and possesses a smaller umbonal angle. Considering its inequivalved condition, we interpret $E$. rugosa to have been pleurothetic, and epibyssate, resting on the right valve.

RANGe AND Distribution: Lower and Middle Permian of West Texas. Specimens are from U.S. Geological Survey locality 2930, Middle Permian, Pine Spring, Guadalupe Mts., West Texas, University of Kansas locality 21 ("Leonardian"), and the following USNM localities (Cooper and Grant, 1972):

\begin{tabular}{|c|c|}
\hline $702 \mathrm{c}$ & Road Canyon Formation \\
\hline $702,702 \mathrm{a}$ & Cathedral Mountain Formation \\
\hline $\begin{array}{c}\text { 701, 701a, } \\
\quad \mathrm{c}, \mathrm{d}, \mathrm{k}\end{array}$ & Neal Ranch Formation \\
\hline $702 \mathrm{~d}, 702 \mathrm{e}$ & $\begin{array}{l}\text { Hess Formation, } \\
\text { Taylor Ranch Member }\end{array}$ \\
\hline $701 \mathrm{e}$ & $\begin{array}{l}\text { Gaptank Formation, } \\
\text { Uddenites-bearing shale member }\end{array}$ \\
\hline
\end{tabular}

\section{ACKNOWLEDGMENTS}

The following persons at the American Museum of Natural History contributed to this project from its inception: Gillian W. Newell helped with every aspect of field and office work; Walter B. Elvers, museum volunteer, assisted with computer technology, draftsmanship, library research, and organization of specimens; and Portia Rollins supplied the photographs. Donald W. Boyd and Thomas E. Yancey provided helpful reviews of the manuscript.

\section{REFERENCES}

Assmann, P.

1937. Revision der Fauna der Wirbellosen der oberschlesischen Trias. Geol. Preuss. Landesanstalt Abh. 170: 1-134.

Cooper, G. A., and R. E. Grant

1972. Permian brachiopods of West Texas, I. Smithson. Contrib. Paleobiol. 14: 231 pp.

Frech, F.

1891. Die devonischen Aviculiden Deutschlands, ein Beitrag zur Systematik und 
Girty, G. H.

Stammesgeschichte der Zweischaler. Geol. Spezialk. Preuss. Abh. 9: 253 pp.

1908. The Guadalupian fauna. U.S. Geol. Surv. Prof. Pap. 58: 651 pp.

Glenister, B. F., et al.

1992. The Guadalupian: proposed international standard for a Middle Permian Series. Int. Geol. Rev. 34(9): 857-888.

McLearn, F. H.

1941. Preliminary descriptions of some new Triassic pelecypods from the Peace River Foothills, B.C. Can. Field-Nat. 55(3): 32-33.
McRoberts, C. A., and N. D. Newell

1997. A new transitional myalinid bivalve from the lower Permian of West Texas. Palaeontology 40(2): 487-495.

Newell, N. D.

1942. Late Paleozoic pelecypods: Mytilacea. Kansas Geol. Surv. Bull. 10(2): 80 pp.

Newell, N. D.

1965. Classification of the Bivalvia. Am. Mus. Novitates 2206: 25 pp.

Newell, N. D., and F. Merchant

1939. Discordant valves in pleurothetic pelecypods. Am. J. Sci. 237: 175-177. 


Recent issues of the Novitates may be purchased from the Museum. Lists of back issues of the Novitates and Bulletin published during the last five years are available at World Wide Web site http://nimidi.amnh.org. Or address mail orders to: American Museum of Natural History Library, Central Park West at 79th St., New York, NY 10024. TEL: (212) 769-5545. FAX: (212) 7695009. E-MAIL: scipubs@amnh.org 